\title{
Posttransplant primary CNS lymphoma
}

\author{
Thanh G. Phan, Brian P. O'Neill, and Paul J. Kurtin \\ Department of Neurology (T.G.P., B.P.O.) and the Division of Hematopathology (P.J.K.), Mayo Clinic and \\ Mayo Foundation, Rochester, MN 55905
}

The records and neuro-imaging studies of 8 cases of posttransplant primary CNS lymphoma (PT-PCNSL) diagnosed at Mayo Clinic Rochester between 1970 and 1998 were reviewed retrospectively. All patients received organ transplantation. Patients who had hematologic transplantation were not included in the analysis. The median and mean age of the 4 men and 4 women was 45 years (range, 34 to 50 years). The median duration of symptoms before diagnosis was 36 days (range, 5 to 98 days). At diagnosis, the neurologic examination was focally abnormal in 6 of 8 patients. Compared with the initial computed tomographic study, MRI showed 25 additional brain lesions. Only $43.7 \%$ of lesions enhanced with contrast agent; of those that did, all but one were heterogeneous. Ependymal contact occurred in 5 patients. MRI lesion burden increased proportionally to the interval between scans. Diagnostic tissue was obtained by stereotactic biopsy from 6 patients and by open biopsy from 2. Hemorrhage occurred in the biopsy area in 4 patients who had stereotactic biopsy and 2 died (all had normal coagulation studies). Slides available for review (7 patients) showed that the tumors were of CD20-positive lineage and were positive for Epstein-Barr virus, using in situ hybridization. Six patients died. Median survival for the cohort was 13 weeks. PT-PCNSL has clinical and imaging features distinct from typical PCNSL. In our series, (1) PT-PCNSL presented nonspecifically and progressed rapidly, (2) stereotactic brain biopsy had significant morbidity, and (3) despite multimodal therapy, survival was poor. NeuroOncology 2, 229-238, 2000 (Posted to Neuro-Oncology

Received 5 June 2000, accepted 17 July 2000.

${ }^{1}$ Supported in part by the Linse Bock Program in Neuro-Oncology, Mayo Clinic Cancer Center, and the National Cancer Institute Cancer Centers Support Grant (P30CA15083), Mayo Clinic Cancer Center, Rochester, MN 55905.

${ }^{2}$ Address correspondence and reprint requests to Brian P. O'Neill, Department of Neurology, Mayo Clinic, 200 First St. SW, Rochester, MN 55905.

${ }^{3}$ Abbreviations used are as follows: EBV, Epstein-Barr virus; PTLD, posttransplant lymphoproliferative disorder; PCNSL, primary CNS

lymphoma; PT-PCNSL, posttransplant primary CNS lymphoma. [serial online], Doc. 00-034, September 13, 2000. URL $<$ neuro-oncology.mc.duke.edu>)

$\mathrm{P}$ T-PCNSL ${ }^{3}$ is an uncommon and potentially fatal side effect of immunosuppression for organ transplantation. The pathogenesis is thought to be related to impairment in the cellular arm ( $\mathrm{T}$ cell) of the immune response, leading to proliferation of $\mathrm{B}$ cells immortalized by EBV (Hanto et al., 1985). Consequently, EBV has been documented by in situ hybridization in almost all patients with PT-PCNSL (Morrison et al., 1994). Before transplantation, the presence of EBV seronegativity and cytomegalovirus sero-mismatch increases the risk of any posttransplant PTLD (Aris et al., 1996; Walker et al., 1995). However, the use of antiviral agents has not been shown to decrease the incidence of PTLD in an EBV-negative person (Aris et al., 1996). The use of immunosuppressive agents such as cyclosporine and rescue drugs in instances of rejection, such as muromonab-CD3 (OKT3), also increases the risk of PTLD (Walker et al., 1995). Deletions of the interferon- $\alpha$ gene have been found in patients with PTLD, and treatment with interferon- $\alpha$ has led to clinical improvement through an effect on type 2 helper T cells (Faro et al., 1996; Wood et al 1997).

The clinical course and neuro-imaging features in PCNSL have been well characterized (Johnson et al., 1997; O'Neill and Illig, 1989; Roman-Goldstein et al., 1992; Schwaighofer et al., 1989; Tomlinson et al., 1995). The typical patient is male, in his seventh decade, and presents with the syndrome of a subacute mass lesion. In rare instances, PCNSL can be preceded by prodromal symptoms and even inflammatory demyelinating lesions (Alderson et al., 1996; Bender and Schapiro, 1989; Brecher et al., 1998; DeAngelis, 1990). The typical MRI features of PCNSL are isointense to hypointense and hyperintense parenchymal masses on T1-weighted, proton density, and T2-weighted scans; homogeneous and intense contrast enhancement; contact with CSF, either at the ependymal or the pial surface; and decreased contrast enhancement in patients given corticosteroids (Jack et al., 1986). Important distinctions have been described between the contrast 
enhancement pattern seen on MRI in PCNSL in immunocompetent patients and in PCNSL associated with acquired immunodeficiency syndrome. In the latter, PCNSL lesions are often multiple and may appear cystlike or necrotic (Johnson et al., 1997).

Although posttransplant systemic non-Hodgkin's lymphoma has been amply described, PT-PCNSL has been described in isolated case reports or as part of cohorts of posttransplant non-Hodgkin's lymphoma (Barnett and Schwartz, 1974; Ciancio et al., 1997; Donnelly et al., 1998; Hardwidge et al., 1990; Krikorian et al., 1978; Kwan et al., 1992; Matas et al., 1976; Miller et al., 1997; Morrison et al., 1994; Murray et al., 1986; Penn and Starlz, 1972a, 1972b; Penn et al., 1969; Schneck and Penn, 1970, 1971; Schwechheimer et al., 1994; Tubman et al., 1983; van Diemen-Steenvoorde et al., 1986; Weintraub and Warnke, 1982). Only 39 such cases have been published in the English language literature (Table 1), and most of these antedate modern neuro-imaging. Furthermore, no study has described serial neuro-imaging evaluations in these patients. Although the method of diagnosis of PCNSL and PT-PCNSL is usually stereotactic brain biopsy (O’Neill et al., 1987), previous reports have not commented on the potential complications of the procedure in this group of patients.

Herein, we report the first single-institution series with clinical, imaging, pathologic, and outcome data of patients with PT-PCNSL and summarize cases reported in the literature.

\section{Methods}

We identified patients with PT-PCNSL by reviewing the data from the Mayo Clinic Tumor Registry, the Lymphoma Registry, and the Mayo Surgical Index between 1970 and 1998. For the purposes of this report, we defined PT-PCNSL as lymphoma involving exclusively the CNS. Although the extent and method of systemic staging varied during the nearly 3 -decade span of this review, no patient had evidence of systemic lymphoma. All patients were negative for antibodies to human immunodeficiency virus and had received organ transplantation. Patients who had hematologic transplantation, including peripheral blood and stem cell transplantation, were not included in the analysis. The total number of organ transplants and the total number and types of systemic and CNS tumors occurring in those patients over the same period of study were available for comparative calculations.

The medical records of the patients were reviewed to define the clinical and neuro-imaging features. Patients 6 and 7 (Table 2) were previously reported as part of an infectious disease study of immunosuppressed patients (Walker et al., 1995). CT was performed on second- and third-generation scanners. CT imaging of Patient 1 was not available for review. CT was the initial imaging modality in 6 patients, and only 2 of these studies were performed with contrast material. All except one patient underwent MRI with a 1.5 -T scanner. Contrast material (gadopentetate, $0.1 \mathrm{mmol} / \mathrm{kg}$ ) was given by i.v. to all 7 patients. For each patient, the neuro-imaging films were reviewed by two of the authors (T.G.P., B.P.O.), and the
Table 1. Characteristics of previously reported patients with posttransplant primary CNS lymphoma

\begin{tabular}{lc} 
Characteristic & Value \\
\hline Age & 28 \\
Mean (year) & 23 \\
Median (year) & $8-52$ \\
Range (year) & 39 \\
No. of patients reported & $4 / 39$ \\
No. of cardiac transplantations & $35 / 39$ \\
No. of renal transplantations & $9 / 15$ \\
No. with solitary lesion on CT & $3 / 7$ \\
No. with EBV viremia & $3 / 11$ \\
No. with CMV viremia & $11 / 15$ \\
No. with rejection & $3 / 39$ \\
No. of survivors at time of report & \\
\hline
\end{tabular}

Abbreviations: CMV, cytomegalovirus; EBV, Epstein-Barr virus.

These patients' characteristics were summarized from previous reports on posttransplant primary CNS lymphoma (Barnett and Schwartz, 1974; Ciancio et al., 1997; Donnelly et al., 1998; Hardwidge et al., 1990; Krikorian et al., 1978; Kwan et al., 1992; Matas et al., 1976; Miller, 1997; Morrison et al., 1994; Murray et al., 1986; Penn and Starlz, 1972a, 1972b; Penn et al., 1969; Schneck and Penn, 1970; Schwechheimer et al., 1994; Tubman et al., 1983; van Diemen-Steenvoorde et al., 1986; Weintraub and Warnke, 1982).

number, size, and locations of the lesions were determined. Conflict resolution was not necessary because all reviews were congruent with the original reports.

A retrospective review (P.J.K.) of the brain biopsy specimens was possible for 7 of the 8 patients. The lymphomas were classified according to the Revised European-American Lymphoma Classification criteria (Harris et al., 1994). PT-PCNSL was further characterized as monomorphic or polymorphic type by the criteria of Nalesnik et al. (1988). In all cases, immunophenotyping studies were performed on either frozen or paraffinembedded tissue using the labeled streptavidin-biotinimmunoperoxidase technique, as previously reported (Kurtin et al., 1999). In addition, in 6 cases, the tumors were assessed for the presence of EBV with in situ hybridization with probes that recognize EBV-encoded RNA (EBER 1 and EBER 2) according to a previously published method (Myers et al., 1995). In 3 cases, sufficient tissue was available to perform Southern blot assays for EBV with a probe that recognizes the terminal repeat sequence of the virus (Raab-Traub and Flynn, 1986; Southern, 1975). Next, the membranes were subjected to autoradiography.

Patients were not treated according to a standard protocol. However, for all patients, the initial treatment consisted of a reduction in immunosuppressive therapy and close surveillance for response. Treatment with cyclosporine (when used) was stopped and treatment with prednisone and azathioprine was reduced to the lowest tolerable dose in all patients. Antiviral treatment with acyclovir or valacyclovir was at the discretion of the treating physician. This treatment was commenced in 5 patients. If there was no evidence of efficacy, the patients were offered whole-brain radiotherapy. Outcome was determined by the duration of survival and the clinical 
Table 2. Characteristics of 8 patients with posttransplant primary CNS lymphoma

\begin{tabular}{|c|c|c|c|c|c|c|c|c|c|c|}
\hline Patient & $\begin{array}{c}\text { Age } \\
\text { (year/sex) }\end{array}$ & $\begin{array}{c}\text { Type } \\
\text { transplant }\end{array}$ & $\begin{array}{l}\text { Immuno- } \\
\text { suppression }\end{array}$ & Rejection & $\begin{array}{c}\text { Functioning } \\
\text { graft }\end{array}$ & $\begin{array}{c}\text { CMV } \\
\text { sero- } \\
\text { mismatch }\end{array}$ & $\begin{array}{l}\text { EBV status } \\
\text { before } \\
\text { transplant }\end{array}$ & $\begin{array}{c}\text { CMV } \\
\text { viremia } \\
\text { within } 3 \text { mo }\end{array}$ & $\begin{array}{c}\text { EBV } \\
\text { viremia } \\
\text { within } 3 \mathrm{mo}\end{array}$ & $\begin{array}{c}\text { Time to } \\
\text { development } \\
\text { PT-PCNSL (mo) }\end{array}$ \\
\hline 1 & $50 / M$ & Kidney & $\begin{array}{l}\text { Prednisone, } \\
\text { azathioprine }\end{array}$ & Yes & Yes & Not known & Not known & NA & NA & 53 \\
\hline 2 & $58 / F$ & Kidney & $\begin{array}{l}\text { Prednisone, } \\
\text { azathioprine, } \\
\text { cyclosporine, } \\
\text { ALG }\end{array}$ & No & Yes & No & Positive & No & NA & 61 \\
\hline 3 & $43 / F$ & Kidney & $\begin{array}{l}\text { Prednisone, } \\
\text { azathioprine, } \\
\text { cyclosporine, } \\
\text { mycophenolate }\end{array}$ & No & No & No & Negative & Yes & Yes & 11 \\
\hline 4 & $50 / M^{a}$ & Kidney & $\begin{array}{c}\text { Prednisone, } \\
\text { azathioprine, } \\
\text { cyclosporine, } \\
\text { muromonoab-CD3 }\end{array}$ & $\begin{array}{l}\text { Yes } \\
3\end{array}$ & No & No & Not known & Yes & NA & 7 \\
\hline 5 & $46 / M$ & $\begin{array}{l}\text { Kidney- } \\
\text { pancreas }\end{array}$ & $\begin{array}{c}\text { Prednisone, } \\
\text { azathioprine, } \\
\text { cyclosporine, } \\
\text { muromonoab-CD3 }\end{array}$ & $\begin{array}{l}\text { Yes } \\
3\end{array}$ & No & Yes & Positive & Yes & No & 4 \\
\hline 6 & $43 / F$ & $\begin{array}{l}\text { Kidney- } \\
\text { pancreas }\end{array}$ & $\begin{array}{c}\text { Prednisone, } \\
\text { azathioprine, } \\
\text { ALG, } \\
\text { cyclosporine, } \\
\text { muromonab-CD3 }\end{array}$ & Yes & Yes & No & Positive & No & No & 12 \\
\hline 7 & $36 / F$ & Liver & $\begin{array}{l}\text { Prednisone, } \\
\text { azathioprine, } \\
\text { cyclosporine, } \\
\text { muromonoab-CD3 }\end{array}$ & $\begin{array}{l}\text { Yes } \\
3\end{array}$ & Yes & Yes & Negative & Yes & No & 3 \\
\hline 8 & $34 / M$ & Lung & $\begin{array}{l}\text { Prednisone, } \\
\text { azathioprine, } \\
\text { cyclosporine }\end{array}$ & No & Yes & Yes & Negative & Yes & No & 4 \\
\hline
\end{tabular}

Abbreviations: CMV, cytomegalovirus; EBV, Epstein-Barr virus; NA, not available; ALG, antilymphoblast globulin; PT-PCNSL, posttransplant CNS lymphoma; muromonoab-CD3, OKT-3. apatient 4 had 2 kidney transplants. Immunosuppression was stopped 4 weeks before diagnosis of PT-PCNSL.

and imaging response to therapy. Before any patient data were reviewed, the study was approved by the Mayo Foundation Institutional Review Board.

\section{Results}

\section{Clinical Features}

The cohort consisted of 8 patients with PT-PCNSL (Table 2). Over the same period (1970-1998), there were 65 cases of posttransplant non-Hodgkin's lymphoma among 2745 organ transplantations (1645 renal transplantations, 73 renal-pancreas transplantations, 860 liver transplantations, 33 lung transplantations, and 134 cardiac transplantations). None of the 134 patients who had a heart transplant developed PT-PCNSL. At Mayo Clinic Rochester, PT-PCNSL occurred in $0.3 \%$ of organ transplantations and $12.4 \%$ of all posttransplant non-Hodgkin's lymphoma cases during the study period.

Seven of the patients received cyclosporine and 4 received muromonab-CD3. Two patients received cyclosporine, muromonab-CD3, and antilymphocyte globulin (Patients 2 and 6, Table 2). The median time to onset of PT-PCNSL was 19 months (range, 3 to 61 months). Most of the patients still maintained a functioning graft, although 5 of the 8 patients experienced graft rejection phenomena. The mean duration of symptoms before diagnosis was 36 days (range, 5 to 98 days). The commonest presenting symptom was lethargy ( 6 patients), followed by headache ( 5 patients), fever (4 patients), and confusion (4 patients). Six patients $(75 \%)$ had focal findings on neurologic examination at diagnosis. One patient (Patient 8) became stuporous because of obstructive hydrocephalus and required emergency placement of a ventricular shunt and a suboccipital craniotomy.

Six patients had opportunistic infections, presumably reflecting the severity of immunosuppression, and of these, 5 had documented cytomegalovirus viremia and 1 had cryptococcal meningitis within 3 months after the diagnosis of PT-PCNSL. All 6 patients who had in situ EBV hybridization studies on brain tissue were positive for the virus. Clonality of EBV was documented in the 2 patients in whom the test was done.

\section{Outcome}

Median survival after the diagnosis of PT-PCNSL was 13 weeks, with the longest survivor alive after 93 months (Table 3). Five patients had intracranial hemorrhages. 
Table 3. Tumor type, treatment, and outcome of 8 patients with posttransplant primary CNS lymphoma

\begin{tabular}{|c|c|c|c|c|c|c|c|c|c|}
\hline Patient & $\begin{array}{l}\text { Tumor } \\
\text { type }\end{array}$ & Necrosis & CD20 & CD3 & EBV-ISH & $\begin{array}{l}\text { Southern } \\
\text { blot for EBV }\end{array}$ & Radiology & Treatment & $\begin{array}{c}\text { Survival after } \\
\text { diagnosis of PT-PCNSL }\end{array}$ \\
\hline 1 & $\begin{array}{c}\text { Diffuse } \\
\text { B-cell } \\
\text { lymphoma } \\
\text { (not reviewed) }\end{array}$ & NA & NA & NA & NA & NA & $\begin{array}{c}\text { R parietal } \\
\text { (contrast } \\
\text { enhancement) }\end{array}$ & $\begin{array}{c}\text { Reduction of } \\
\text { immunosuppression } \\
\text { local brain } \\
\text { radiotherapy } 4600 \text { cGy }\end{array}$ & $\begin{array}{c}32 \mathrm{mo} \\
\text { (died of } \\
\text { pulmonary embolism) } \\
\text { No recurrence of PT-PCNSL }\end{array}$ \\
\hline 2 & $\begin{array}{c}\text { Mono-morphic } \\
\text { B-cell } \\
\text { lymphoma }\end{array}$ & Yes & + & - & NA & $\begin{array}{l}\text { Single } \\
\text { EBV-specific } \\
\text { band }\end{array}$ & $\begin{array}{c}\text { Ependymal contact, } \\
\text { caudate (homogeneous } \\
\text { enhancement), enlarged } \\
\text { ventricles }\end{array}$ & $\begin{array}{c}\text { Ceased } \\
\text { immunosuppression } \\
\text { only }\end{array}$ & $\begin{array}{c}2 \text { wk } \\
\text { (died; no autopsy) }\end{array}$ \\
\hline 3 & $\begin{array}{c}\text { Mono-morphic } \\
\text { B-cell } \\
\text { lymphoma }\end{array}$ & No & + & - & + & NA & $\begin{array}{c}\text { Cerebellar peduncle } \\
\text { (ring enhancement), } \\
\text { new white matter lesions } \\
16 \text { days later \& meningeal } \\
\text { enhancement }\end{array}$ & $\begin{array}{l}\text { Cyclosporine ceased } \\
\text { acyclovir, whole-brain } \\
\text { radiotherapy } 5000 \text { cGy; } \\
\text { followed by rejection } \\
\text { requiring higher dose } \\
\text { of prednisone }\end{array}$ & 6 mo (alive) \\
\hline 4 & $\begin{array}{c}\text { Mono-morphic } \\
\text { B-cell } \\
\text { lymphoma }\end{array}$ & No & + & - & + & NA & $\begin{array}{l}\text { Ependymal contact, } \\
\text { periventricular (ring } \\
\text { enhancement) \& thalamus, } \\
\text { cerebral peduncle, pons, } \\
\text { cerebellum, white matter } \\
\text { lesions; meningeal } \\
\text { enhancement }\end{array}$ & $\begin{array}{c}\text { Off immunosuppression } \\
4 \text { weeks before } \\
\text { diagnosis of PTLD }\end{array}$ & $\begin{array}{c}1 \text { day } \\
\text { (died of } \mathrm{ICH} \\
\text { after brain biopsy) }\end{array}$ \\
\hline 5 & $\begin{array}{c}\text { Mono-morphic } \\
\text { B-cell } \\
\text { lymphoma }\end{array}$ & Yes & + & - & + & $\begin{array}{l}\text { Single } \\
\text { EBV-specific } \\
\text { band }\end{array}$ & $\begin{array}{l}\text { Ependymal contact, caudate, } \\
\text { white matter lesions, } \\
\text { (misdiagnosed as infarcts); } \\
\text { subtle contrast enhancement; } \\
\text { intracerebral hemorrhage } \\
\text { after biopsy }\end{array}$ & $\begin{array}{c}\text { Cyclosporine ceased, } \\
\text { acyclovir, } \\
\text { palliative whole- } \\
\text { brain radiotherapy } \\
1080 \text { cGy }\end{array}$ & $\begin{array}{c}1 \mathrm{wk} \\
\text { (died of ICH } \\
\text { after brain biopsy) }\end{array}$ \\
\hline 6 & $\begin{array}{c}\text { Mono-morphic } \\
\text { B-cell } \\
\text { lymphoma }\end{array}$ & Yes & + & - & + & NA & $\begin{array}{l}\mathrm{L} \text { frontal glioblastoma } \\
\text { multiforme-like lesion, } \\
\text { heterogeneous contrast } \\
\text { enhancement; edema }\end{array}$ & $\begin{array}{c}\text { Azathioprine ceased, } \\
\text { acyclovir, } \\
\text { whole-brain radiotherapy } \\
5040 \text { cGy, CHOP (1 cycle) }\end{array}$ & $\begin{array}{c}86 \text { mo } \\
\text { (died; no autopsy) }\end{array}$ \\
\hline 7 & $\begin{array}{c}\text { Mono-morphic } \\
\text { B-cell } \\
\text { lymphoma }\end{array}$ & Yes & + & - & + & NA & $\begin{array}{l}\text { Ependymal contacts, } \\
\text { caudate, putamen, centrum } \\
\text { semiovale (hemorrhage), } \\
\text { frontal, temporal white } \\
\text { matter lesions }\end{array}$ & $\begin{array}{c}\text { Reduction of } \\
\text { immunosuppression, } \\
\text { whole-brain } \\
\text { radiotherapy } 4980 \text { cGy }\end{array}$ & 93 mo (alive) \\
\hline 8 & $\begin{array}{c}\text { Mono-morphic } \\
\text { B-cell } \\
\text { lymphoma }\end{array}$ & Yes & + & - & + & NA & $\begin{array}{c}\text { Ependymal contact, } \\
\text { cerebellar (heterogeneous } \\
\text { enhancement \& edema), } \\
\text { frontal, caudate, white matter } \\
\text { lesions, obstructive } \\
\text { hydrocephalus; meningeal } \\
\text { enhancement }\end{array}$ & $\begin{array}{l}\text { Debulking, valacyclovir, } \\
\text { ceased azathioprine }\end{array}$ & $\begin{array}{l}2 \text { wk (died; no autopsy) } \\
\text { Hemorrhage after shunt }\end{array}$ \\
\hline
\end{tabular}

Abbreviations: EBV, Epstein-Barr virus; ISH, in situ hybridization; PT-PCNSL, posttransplant CNS lymphoma; NA, not available; R, right; PTLD, posttransplant lymphoproliferative disorder; $\mathrm{ICH}$, intracerebral hemorrhage; L, left; CHOP, cyclophosphamide, hydroxydaunomycin (doxorubicin), vincristine (Oncovin), prednisone.

Hemorrhage occurred at the biopsy site in 4 patients (Patients 4-7) who had stereotactic biopsies and along the course of a ventricular catheter in the patient (Patient 8) who required an emergency shunt. Two patients died of parenchymal hemorrhage. Antiviral therapy had no effect on the progression of lymphoma in our patients. This step-up regimen from reduction of immunosuppression to radiotherapy was possible in only 4 patients.

\section{CSF Analysis}

The CSF was analyzed in all 8 patients and in 6 of them (Patients 1-3, 5, 7, and 8) while they were still receiving their usual dose of immunosuppressive drugs (Table 4). In Patient 4, treatment with all immunosuppressive agents ceased 4 weeks before CSF analysis because of a nonfunctioning graft, and in Patient 6, cyclosporine treatment had stopped 9 months before CSF analysis because of a presumed drug-related leukoencephalopathy. CSF findings were normal in 2 patients and nonspecifically abnormal in the other 6 . The most common finding was an increased protein concentration (median, $72 \mathrm{mg} / \mathrm{dl}$ ).

Results of CSF flow cytometry were abnormal in 1 (Patient 5) of the 2 patients in whom it was performed. Five CSF analyses were performed over 8 weeks in Patient 2 to monitor treatment of cryptococcal meningitis. Despite serial CSF examinations, the development of PT-PCNSL in this patient was not heralded by abnormal cytologic findings or by an increase in the CSF cell count or protein concentration, but by the development of new 
neurologic symptoms. In the one patient (Patient 3) who had polymerase chain reaction performed, the results were negative for both EBV and cytomegalovirus. None of the patients had any complication from lumbar puncture. In one patient (Patient 7), CSF was obtained at the time of ventricular shunting.

\section{Neuro-imaging}

The initial CT findings were abnormal in 4 of the 6 patients in whom the study was performed, and the PT-PCNSL lesions varied in appearance from hypodense to moderately hyperdense. In one patient, the hypodense area was initially interpreted as subcortical infarction. Contrast enhancement occurred in one-third of these CT-visible lesions. Heterogeneous enhancement was the predominant pattern (as it was with enhancement on MRI). Two symptomatic patients had normal CT findings (Fig. 1).

Overall, 25 more lesions were seen on the initial MRI performed 1 to 15 days after the initial CT examination. A second MRI study was performed in 5 patients and showed 9 additional lesions. Lesion size ranged from 5 to $40 \mathrm{~mm}$. Of the 32 lesions seen on the initial MRI studies in 7 patients, $13(40.6 \%)$ were located in the basal ganglia, $8(25 \%)$ in the frontal lobe, $3(9 \%)$ were in the temporal lobe, $3(9 \%)$ in the brain stem, and $3(9 \%)$ in the cerebellum. There was ependymal contact in 5 patients, 4 of whom died. The lesions were well defined and appeared hypointense on T1-weighted and

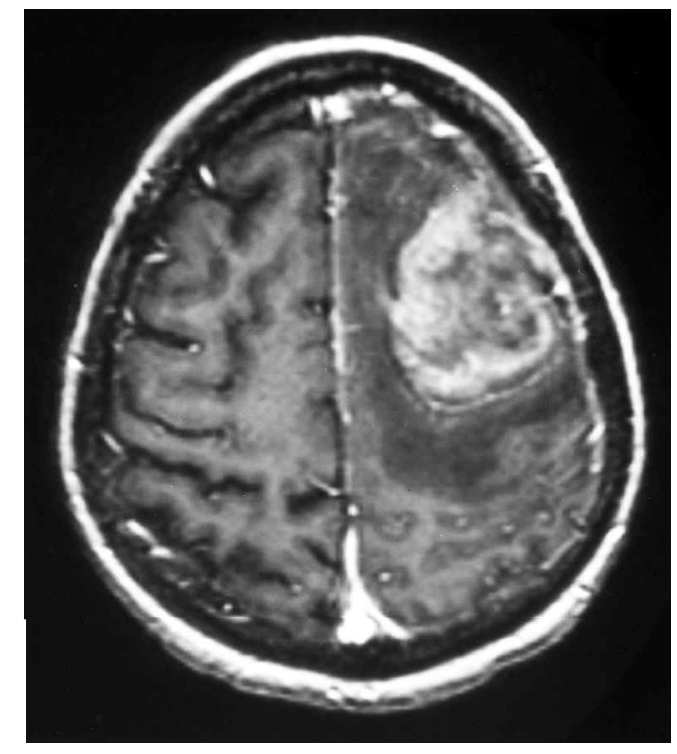

Fig. 2. T1-weighted MRI with gadolinium showing lesion resembling high-grade glioma (Patient 6).

T2-weighted sequences or as a high signal T2 rim with a hypointense center on T1-weighted and T2-weighted sequences. Uncommonly, a lesion appeared as heterogeneously hyperintense on T2- and isointense on T1weighted sequences (Patients 4 and 7).

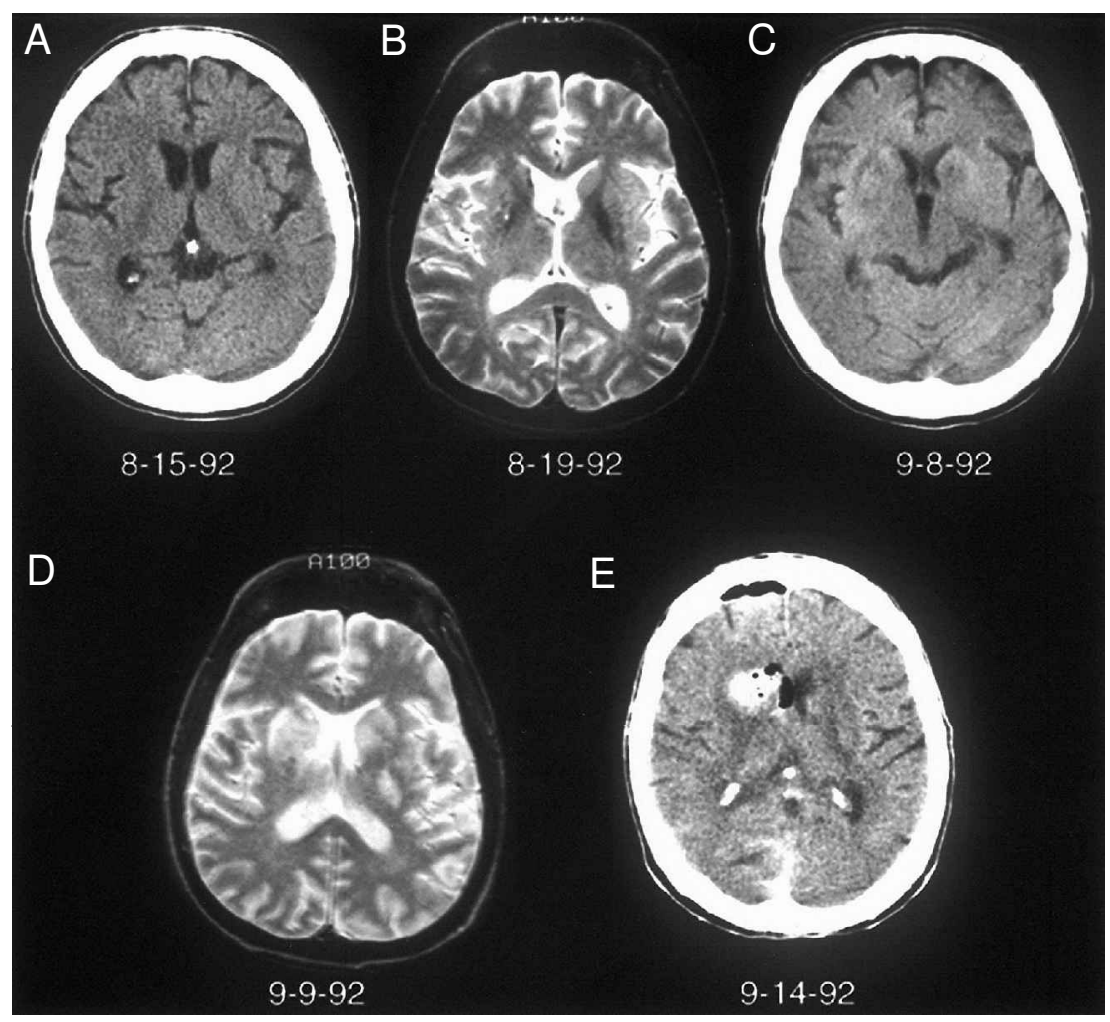

Fig. 1. CT study in Patient 5. (A-D) Alternating noncontrast CT and T2-weighted MRI scans of delayed evolution to abnormal imaging results despite onset of dysphasia and left hemiparesis 3 days previously. T2-weighted sequence on 8/19/92 showed evidence of minimal hemosiderin deposition that suggested an old hemorrhage in the lesion. (E) CT showing hemorrhage after biopsy. 

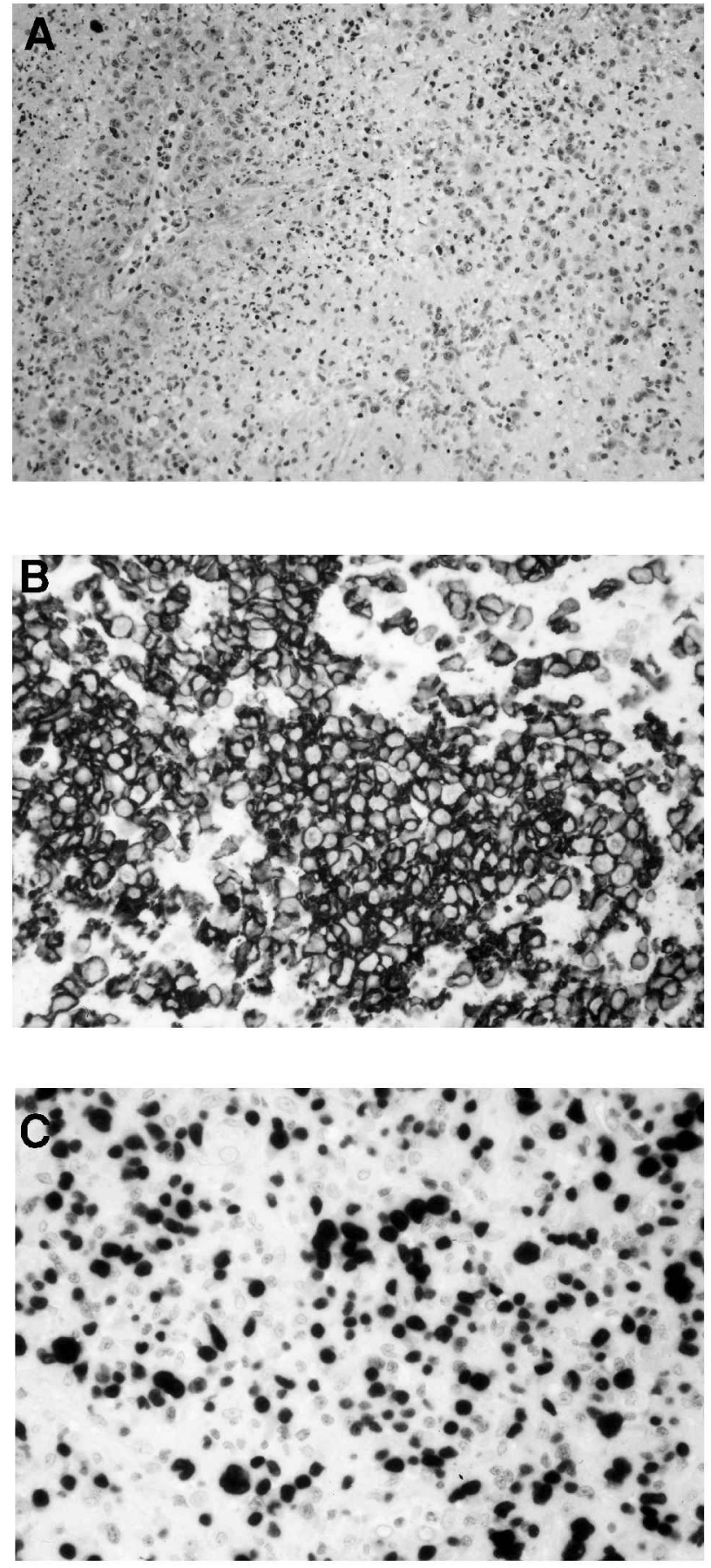

Fig. 3. Histologic features in tissue samples. (A) Architectural features of diffuse large B-cell lymphoma. Note prominent perivascular tumor cell infiltrates (left), diffuse infiltration of cerebral parenchyma (right), and central focus of necrosis. (Hematoxylin and eosin; original magnification $\times 200$.). (B) Immunoperoxidase stain for CD20 in posttransplant primary CNS lymphoma. The membrane staining of lymphoma cells is strong for B-cell lineage antigen, CD20. (Immunoperoxidase stain, aminoethyl carbazole chromagen and hematoxylin counterstain; original magnification $\times 400$.). (C) In situ hybridization for Epstein-Barr virus in posttransplant primary CNS lymphoma. Nearly all lymphoma cells exhibit strong, uniform nuclear staining for Epstein-Barr virus. (In situ hybridization for Epstein-Barr virus, nitroblue tetrazolium chromagen, nuclear fast red counterstain; original magnification $\times 400$.)
On MRI, contrast enhancement occurred in only $44 \%$ of the lesions (all the patients except Patient 4 were taking corticosteroids at the time of the scan). Homogeneous enhancement occurred in only one patient (Patient 2). The rest had rim enhancement or heterogeneous enhancement. In one patient, the MRI features resembled those of a highgrade glioma because of the vasogenic edema, heterogeneous T2 signal abnormality, and heterogeneous contrast enhancement, giving a "necrotic" appearance (Fig. 2). Each of the progressively multiple lesions seen on serial MRI scans also had variable enhancement with contrast agent.

A mass effect was seen in 3 patients (Patients 6, 7, and 8 ) and was associated with a poor outcome only in Patient 8 , who required emergency craniectomy and ventricular shunting because of a cerebellar vermal lesion that caused displacement of the fourth ventricle and partial obstructive hydrocephalus. Meningeal enhancement was seen in 3 patients (Patients 3, 4, and 8). In Patient 3, the MRI features proceeded from normal to abnormal T2 signal to gadolinium contrast enhancement of the parenchyma and, eventually, the meninges.

\section{Brain Biopsy and Hemorrhage}

Stereotactic biopsy was performed in 6 patients and open biopsy in the other 2. Hemorrhage occurred at the biopsy site in 4 patients (Patients 4-7) who had stereotactic biopsy and one other patient had hemorrhage along the track of the external ventricular drain. Two of these patients died of hemorrhage: 1 died 1 day after biopsy of a caudate lesion and the other died 1 week after biopsy of a thalamic lesion. Delayed hemorrhage occurred at the biopsy site and other sites after radiotherapy in Patient 7. No risk factors, such as lesional hemorrhage on preoperative neuro-imaging or abnormal coagulation studies, were identified. Although no hemorrhage was apparent on the preoperative CT study in Patient 5, MRI showed evidence of minimal hemosiderin deposition that suggested an old hemorrhage in the lesion (Fig. 1).

\section{Pathology}

Similar histologic features were observed in all 7 tissue samples and are illustrated in Fig. 3. Five of the 7 tissue samples had foci of necrosis. In all 7 samples, the neoplastic cells were $\mathrm{CD} 20^{+} \mathrm{CD}^{-} \mathrm{B}$ cells, and in all 6 samples studied with in situ hybridization, the cells were strongly positive for EBV. Clonality was assessed with the EBV terminal repeat assay in 3 samples, and a single dominant band was observed in all of them, indicating the presence of EBV and clonality of the lymphoma. Using the Revised European-American Lymphoma classification, the neoplasms would be classified as diffuse large B-cell lymphomas. Using the criteria of Nalesnik et al. (1988) for classification of PTLD, all would be included in the monomorphic category.

\section{Discussion}

The present study has several limitations. One, it is a retrospective study from a single institution and, thus, has 
Table 4. CSF profile of 8 patients with posttransplant primary CNS lymphoma

\begin{tabular}{lcccccccc} 
Patient & $\begin{array}{c}\text { Glucose } \\
(\mathrm{mg} / \mathrm{dl})\end{array}$ & $\begin{array}{c}\text { Protein (normal, } \\
14-45 \mathrm{mg} / \mathrm{dl})\end{array}$ & $\begin{array}{c}\text { Number of } \\
\text { nucleated cells }\end{array}$ & Cytology & $\begin{array}{c}\text { Flow } \\
\text { cytometry }\end{array}$ & $\begin{array}{c}\text { EBV PCR } \\
\text { from CSF }\end{array}$ & $\begin{array}{c}\text { CMV PCR } \\
\text { from CSF }\end{array}$ & $\begin{array}{c}\text { Meningeal } \\
\text { involvement }\end{array}$ \\
\hline 1 & 48 & 173 & 0 & Normal & NA & NA & NA & No \\
2 & 53 & 36 & 5 & Normal & NA & NA & NA & No \\
3 & 72 & 97 & 34 & Normal & No monoclonal B cells & Negative & Negative & Yes \\
4 & 32 & 55 & 3 & Normal & NA & NA & NA & Yes \\
5 & 29 & 89 & 13 & Abnormal & B lymphoid cells & NA & NA & No \\
6 & 48 & 20 & 4 & Normal & NA & NA & NA & No \\
7 & 53 & 70 & 10 & Normal & NA & NA & NA & No \\
8 & 59 & 74 & 1 & Normal & NA & NA & NA & Yes \\
\hline
\end{tabular}

Abbreviations: EBV, Epstein-Barr virus; $\mathrm{PCR}$, polymerase chain reaction; $C M V$, cytomegalovirus; $\mathrm{NA}$, not available.

an inherent selection bias. Two, because of the small number of patients studied, generalizations cannot be made about the clinical and neuro-imaging characteristics or treatment of PT-PCNSL. Nevertheless, there are several noteworthy differences between our cohort and the 39 cases of PT-PCNSL reported in the English language literature. Of the 39 reported patients, only 4 had cardiac transplantation and most had renal transplantation (Barnett and Schwartz, 1974; Ciancio et al., 1997; Donnelly et al., 1998; Hardwidge et al., 1990; Krikorian et al., 1978; Kwan et al., 1992; Matas et al., 1976; Miller et al., 1997; Morrison et al., 1994; Murray et al., 1986; Penn et al., 1969; Schneck and Penn, 1970, 1971; Penn and Starlz, 1972a, 1972b; Schwechheimer et al., 1994; Tubman et al., 1983; van Diemen-Steenvoorde et al., 1986; Weintraub and Warnke, 1982). The patients in our cohort were older, and there was no sex bias in our series and no sex bias in the reported cases. The median time from transplantation to onset of PT-PCNSL in the literature (12.6 months; range, 2 to 50 months) was similar to that in our series. None of our patients were children or adolescents, but 6 of the 39 reported patients were younger than 14 years (Penn et al., 1969). Altogether, only 5 of the 39 patients had onset of PT-PCNSL more than 36 months after transplantation (Barnett and Schwartz, 1974; Ciancio et al., 1997; Donnelly et al., 1998; Hardwidge et al., 1990; Kwan et al., 1992; Krikorian et al., 1978; Matas et al., 1976; Miller et al., 1997; Morrison et al., 1994; Murray et al., 1986; Penn and Starlz, 1972a, 1972b; Penn et al., 1969; Schneck and Penn, 1970, 1971; Schwechheimer et al., 1994; Tubman et al., 1983; van Diemen-Steenvoorde et al., 1986; Weintraub and Warnke, 1982). The predominance of cases of PT-PCNSL among patients with kidney or kidney and pancreas transplants in our cohort and in those reported in the literature may represent a selection bias (these transplantations have been performed for a longer period and more frequently than for other organs). However, the low incidence of PT-PCNSL among heart, lung, and liver transplant recipients may indicate a biologic predisposition from disease or treatment. Nevertheless, there currently is no difference between the various transplant types in terms of selecting patients based on EBV status, but individual variations may exist in matching cytomegalovirus donor-recipient status (Arcasoy and Kotloff, 1999; McGiffin et al., 1997; Walker et al.,
1995). The 3 standard immunosuppressive agents for organ transplantation are prednisone, azathioprine, and cyclosporine. Newer agents such as tacrolimus and mycophenolate mofetil are beginning to be used clinically; however, this would not have been soon enough to have affected the higher incidence of PT-PCNSL among renal transplant recipients, and these drugs are used more often in lung and liver than in renal transplantation (Arcasoy and Kotloff, 1999).

PT-PCNSL has clinical and imaging features distinctly different from those of typical PCNSL. In our series, PT-PCNSL presented nonspecifically and generally progressed rapidly clinically and on serial imaging studies. In typical PCNSL, the median duration of symptoms is 8 weeks, compared with 5 weeks in our patients (Tomlison et al., 1995). Admittedly, transplant recipients may be tested more frequently than other patients, leading to earlier detection. However, in some patients, the disease had a protracted course. Patients 2 and 6 had symptoms for a long period, and lumbar puncture and serial neuro-imaging studies did not disclose the diagnosis. These patients also recently had had an opportunistic infection, which may have masked the development or presentation of PT-PCNSL.

MRI was the preferred imaging technique in our cohort for several reasons. The number of lesions identified on MRI was greater than that on CT with contrast agent and response to therapy can be monitored. The better resolution of tissue characteristics on MRI is valuable in immunosuppressed patients, because the differential diagnosis is broader and the imaging appearance more varied. The characteristic feature of PT-PCNSL in this cohort is the variable T2-signal characteristic and the heterogeneous enhancement or rim enhancement with contrast. This may be related to necrosis seen on histologic examination (Johnson et al., 1997). The pattern of progressive heterogeneous contrast enhancement, multiplicity of the lesions, and the predisposition to ependymal location is similar to that seen in PCNSL in acquired immunodeficiency syndrome patients (Johnson et al., 1997). In contrast, PCNSL in immunocompetent patients has homogeneous enhancement with contrast agent. (Johnson et al., 1997; Roman-Goldstein et al., 1992). The neuro-imaging data from the cases of PT-PCNSL reported in the literature are limited and are not sufficient to make comparisons (Barnett and Schwartz, 1974; 
Ciancio et al., 1997; Donnelly et al., 1998; Hardwidge et al., 1990; Krikorian et al., 1978; Kwan et al., 1992; Matas et al., 1976; Miller et al., 1997; Morrison et al., 1994; Murray et al., 1986; Penn and Starlz, 1972a, 1972b; Penn et al., 1969; Schneck and Penn, 1970, 1971; Schwechheimer et al., 1994; Tubman et al., 1983; van Diemen-Steenvoorde et al., 1986; Weintraub and Warnke, 1982).

To our knowledge, the relationship between brain biopsy and hemorrhage in PT-PCNSL has not been reported previously, even in immunocompetent patients with PCNSL (Johnson et al., 1997; Roman-Goldstein et al., 1992; Schwaighofer et al., 1989; Sherman et al., 1991; Tomlinson et al., 1995). Delayed hemorrhage at the biopsy site and hemorrhage at other sites, as in one of our patients, suggest that it may be a characteristic of PTPCNSL rather than a fault of the biopsy technique. There are reports of hemorrhage, before treatment, in PCNSL associated with acquired immunodeficiency syndrome and rare reports of hemorrhage in PCNSL in immunocompetent patients and as a late complication after treatment of childhood CNS lymphoma (Claviez et al., 1998; Fukui et al., 1998; Kothbauer et al., 1979; Poussaint et al., 1995; Zimmerman and Bilaniuk, 1980). However, no predictive characteristics, either of the patient or of the neuro-imaging features, were identified to guide biopsy. Although acute hemorrhage was associated with death in 2 patients, the patient who had delayed hemorrhage had the best long-term outcome.

The pattern of spread of PT-PCNSL in Patient 3 was from a parenchymal lesion to involvement of the meninges. This suggests that PCNSL, or at least PTPCNSL, may be an "inside-out" rather than an "outsidein" process (DeAngelis, 1999). Furthermore, our group of patients demonstrated that contrast enhancementoften thought pathognomonic for PCNSL - may be a late phenomenon and may depend on many factors, including cytokine release, perivascular "cuffing," and endothelial cell disruption (Molnar et al., 1999). Patient 3 demonstrates the pitfalls of MRI studies in early stages of the disease. Conversely, the absence of this pattern in the other patients may indicate only that MRI was performed at a well-advanced stage of disease.

In our series, CSF examination was helpful only in showing inflammation in the CNS, indicating a need to focus investigation in this area. Although an increase in CSF protein concentration correlates with involvement of the meninges, this was not necessarily the case in our cohort (Balmaceda et al., 1995). Only one of our patients had positive cytologic findings. The nonspecific clinical features and CSF findings in our series could have been the result of masking by continuation of corticosteroid and other immunosuppressive therapy. Unlike PCNSL in acquired immunodeficiency syndrome patients, we cannot recommend complete cessation of immunosuppressive therapy for this evaluation because of the risk of rejection in transplant recipients. Brink et al. (1998) suggested that the presence of EBV in CSF of patients with human immunodeficiency virus infection is strongly suggestive of PCNSL. Our experience is limited with this technique in the diagnosis of PCNSL, but reports in the literature suggest this technique has promise in the early diagnosis of PCNSL in immunocompromised patients (Brink et al., 1998).

The poor outcome in monomorphic PT-PCNSL in our cohort, despite multimodal therapy, was disappointing. This was similar to the experience reported in the literature, in which only 3 of the 39 patients were alive at the time of the reports comparisons (Barnett and Schwartz, 1974; Ciancio et al., 1997; Donnelly et al., 1998; Hardwidge et al., 1990; Krikorian et al., 1978; Kwan et al., 1992; Matas et al., 1976; Miller et al., 1997; Morrison et al., 1994; Murray et al., 1986; Schneck and Penn, 1970, 1971; Penn and Starlz, 1972a, 1972b; Penn et al., 1969; Schwechheimer et al., 1994; Tubman et al., 1983; van Diemen-Steenvoorde et al., 1986; Weintraub and Warnke, 1982). Sequential stepup therapy may not be the approach to take for patients with PT-PCNSL. Because all patients who survived had received the combination of antiviral therapy, reduced immunosuppressive therapy, and radiotherapy, perhaps all modalities should be combined at the outset of treatment.

Whether even more modalities should be used is open to debate and likely awaits future discoveries in the pathogenesis of PT-PCNSL and, indeed, PCNSL. Because PT-PCNSL is morphologically and immunologically similar to its systemic counterparts, adapting the treatment regimens of those diseases to the special needs of the CNS may be worthwhile.

\section{Acknowledgments}

We thank Leslie B. Ottjes for secretarial assistance and Kay M. Ristow for maintaining the Mayo Lymphoma Project database.

\section{References}

Alderson, L., Fetell, M.R., Sisti, M., Hochberg, F., Cohen, M., and Louis, D.N. (1996) Sentinel lesions of primary CNS lymphoma. J. Neurol. Neurosurg. Psychiatry 60, 102-105.

Arcasoy, S.M., and Kotloff, R.M. (1999) Lung transplantation. N. Engl. J. Med. 340, 1081-1091

Aris, R.M., Maia, D.M., Neuringer, I.P., Gott, K., Kiley, S., Gertis, K., and Handy, J. (1996) Post-transplantation lymphoproliferative disorder in the
Epstein-Barr virus-naive lung transplant recipient. Am. J. Respir. Crit. Care Med. 154, 1712-1717.

Balmaceda, C., Gaynor, J.J., Sun, M., Gluck, J.T., and DeAngelis, L.M. (1995) Leptomeningeal tumor in primary central nervous system lymphoma: Recognition, significance, and implications. Ann. Neurol. 38, 202-209.

Barnett, L.B., and Schwartz, E. (1974) Cerebral reticulum cell sarcoma after multiple renal transplants. J. Neurol. Neurosurg. Psychiatry 37, 966-970. 
Bender, G.P., and Schapiro, R.T. (1989) Primary CNS lymphoma presenting as multiple sclerosis: A case study. Minn. Med. 72, 157-160.

Brecher, K., Hochberg, F.H., Louis, D.N., de la Monte, S., and Riskind, P. (1998) Case report of unusual leukoencephalopathy preceding primary CNS lymphoma. J. Neurol. Neurosurg. Psychiatry 65, 917-920.

Brink, N.S., Sharvell, Y., Howard, M.R., Fox, J.D., Harrison, M.J., and Miller, R.F. (1998) Detection of Epstein-Barr virus and Kaposi's sarcoma-associated herpesvirus: DNA in CSF from persons infected with HIV who had neurological disease. J. Neurol. Neurosurg. Psychiatry 65, 191-195.

Ciancio, G., Siquijor, A.P., Burke, G.W., Roth, D., Cirocco, R., Esquenazi, V., Byrne, G.E., Jr., and Miller, J. (1997) Post-transplant lymphoproliferative disease in kidney transplant patients in the new immunosuppressive era. Clin. Transplant. 11, 243-249.

Claviez, A., Neubauer, B., Link, J., and Schneppenheim, R. (1998) Intracerebral hemorrhage as a late complication after CNS treatment of childhood lymphoma. Klin. Padiatr. 210, 406-408.

DeAngelis, L.M. (1990) Primary central nervous system lymphoma imitates multiple sclerosis (1990). J. Neurooncol. 9, 177-181.

DeAngelis, L.M. (1999) Primary central nervous system lymphoma. J. Neurol. Neurosurg. Psychiatry 66, 699-701.

Donnelly, L.F., Frush, D.R., Marshall, K.W., and White, K.S. (1998) Lymphoproliferative disorders: $\mathrm{CT}$ findings in immunocompromised children. $A J R$. Am. J. Roentgenol. 171, 725-731.

Faro, A., Kurland, G., Michaels, M.G., Dickman, P.S., Greally, P.G., Spichty, K.J., Noyes, B.B., Boas, S.R., Fricker, F.J., Armitage, J.M., and Zeevi, A. (1996) Interferon-alpha affects the immune response in post-transplant lymphoproliferative disorder. Am. J. Respir. Crit. Care Med. 153, 1442-1447.

Fukui, M.B., Livstone, B.J., Meltzer, C.C., and Hamilton, R.L. (1998) Hemorrhagic presentation of untreated primary CNS lymphoma in a patient with AIDS. AJR. Am. J. Roentgenol. 170, 1114-1115.

Hanto, D.W., Frizzera, G., Gajl-Peczalska, K.J., and Simmons, R.L. (1985) Epstein-Barr virus, immunodeficiency, and B cell lymphoproliferation. Transplantation 39, 461-472.

Hardwidge, C., Diengdoh, J.V., Husband, D., and Nash, J.R. (1990) Primary cerebral lymphoma-a clinico-pathological study. Clin. Neuropathol. 9, 217-223.

Harris, N.L., Jaffe, E.S., Stein, H., Banks, P.M., Chan, J.K., Cleary, M.L., Delsol, G., De Wolf-Peeters, C., Falini, B., Gatter, K.C., Grogan, T.M., Isaacson, P.G., Knowles, D.M., Mason, D.Y., Muller-Hermelink, H.-K., Pileri, S.A., Piris, M.A., Ralfkiaer, E., and Warnke, R.A. (1994) A revised EuropeanAmerican classification of lymphoid neoplasms: A proposal from the International Lymphoma Study Group. Blood 84, 1361-1392.

Jack, C.R., Jr., Reese, D.F., and Scheithauer, B.W. (1986) Radiographic findings in 32 cases of primary CNS lymphoma. AJR. Am. J. Roentgenol. 146, 271-276.

Johnson, B.A., Fram, E.K., Johnson, P.C., and Jacobowitz, R. (1997) The variable MR appearance of primary lymphoma of the central nervous system: Comparison with histopathologic features. AJNR Am. J. Neuroradiol. 18, 563-572.

Kothbauer, P., Jellinger, K., and Falment, H. (1979) Primary brain tumour presenting as spontaneous intracerebral haemorrhage. Acta Neurochir. (Wein) 49, 35-45.

Krikorian, J.G., Anderson, J.L., Bieber, C.P., Penn, I., and Stinson, E.B. (1978) Malignant neoplasms following cardiac transplantation. JAMA 240, 639-643.

Kurtin, P.J., Hobday, K.S., Ziesmer, S., and Caron, B.L. (1999) Demonstration of distinct antigenic profiles of small B-cell lymphomas by paraffin section immunohistochemistry. Am. J. Clin. Pathol. 112, 319-329.

Kwan, J.T., Cotter, F.E., Pollock, L.E., Altmann, P., Lord, R.H., Raftery, M.J., and Cunningham, J. (1992) EBV-genome positive monoclonal B cell cerebral lymphoma in a renal allograft recipient following OKT3 therapy. Nephrol. Dial. Transplant. 7, 360-361.
Matas, A.J., Hertel, B.F., Rosai, J., Simmons, R.L., and Najarian, J.S. (1976) Post-transplant malignant lymphoma: Distinctive morphologic features related to its pathogenesis. Am. J. Med. 61, 716-720.

McGiffin, D.C., Kirklin, J.K., Naftel, D.C., and Bourge, R.C. (1997) Competing outcomes after heart transplantation: A comparison of eras and outcomes. Heart Lung Transplant. 16, 190-198.

Miller, W.T., Jr., Siegel, S.G., and Montone, K.T. (1997) Posttransplantation lymphoproliferative disorder: Changing manifestations of disease in a renal transplant population. Crit. Rev. Diagn. Imaging 38, 569-585.

Molnar, P.P., O'Neill, B.P., Scheithauer, B.W., and Groothuis, D.R. (1999) The blood-brain barrier in primary CNS lymphomas: Ultrastructural evidence of endothelial cell death. Neuro-Oncology [serial online], Doc. 98-09, April 30, 1999. URL <neuro-oncology.mc.duke.edu>. J. Neurooncol. 1, 89-100.

Morrison, V.A., Dunn, D.L., Manivel, J.C., Gajl-Peczalska, K.J., and Peterson, B.A. (1994) Clinical characteristics of post-transplant lymphoproliferative disorders. Am. J. Med. 97, 14-24.

Murray, K., Kun, L., and Cox, J. (1986) Primary malignant lymphoma of the central nervous system: Results of treatment of 11 cases and review of the literature. J. Neurosurgery 65: 600-607.

Myers, J.L., Kurtin, P.J., Katzenstein, A.L., Tazelaar, H.D., Colby, T.V., Strickler, J.G., Lloyd, R.V., and Isaacson, P.G. (1995) Lymphomatoid granulomatosis. Evidence of immunophenotypic diversity and relationship to EpsteinBarr virus infection. Am. J. Surg. Pathol. 19, 1300-1312.

Nalesnik, M.A., Jaffe, R., Starzl, T.E., Demetris, A.J., Porter, K., Burnham, J.A., Makowka, L., Ho, M., and Locker, J. (1988) The pathology of posttransplant lymphoproliferative disorders occurring in the setting of cyclosporine A-prednisone immunosuppression. Am. J. Pathol. 133, 173-192.

O'Neill, B.P., and Illig, J. (1989) Primary central nervous system lymphoma. Mayo Clin. Proc. 64, 1005-1020.

O'Neill, B.P., Kelly, P.J., Earle, J.D., Scheithauer, B., and Banks, P.M. (1987) Computer-assisted stereotaxic biopsy for the diagnosis of primary central nervous system lymphoma. Neurology 37, 1160-1164.

Penn, I., and Starzl, T.E. (1972a) A summary of the status of de novo cancer in transplant recipients. Transplant. Proc. 4, 719-732.

Penn, I., and Starzl, T.E. (1972b) Malignant tumors arising de novo in immunosuppressed organ transplant recipients. Transplantation 14, 407-417.

Penn, I., Hammond, W., Brettschneider, L., and Starzl, T.E. (1969) Malignant lymphomas in transplantation patients. Transplant. Proc. 1, 106-112.

Poussaint, T.Y., Siffert, J., Barnes, P.D., Pomeroy, S.L., Goumnerova, L.C., Anthony, D.C., Sallan, S.E., and Tarbell, N. (1995) Hemorrhagic vasculopathy after treatment of central nervous system neoplasia in childhood: Diagnosis and follow-up. AJNR Am. J. Neuroradiol. 16, 693-699.

Raab-Traub, N., and Flynn, K. (1986) The structure of the termini of the EpsteinBarr virus as a marker of clonal cellular proliferation. Cell 47, 883-889.

Roman-Goldstein, S.M., Goldman, D.L., Howieson, J., Belkin, R., and Neuwelt, E.A. (1992) MR of primary CNS lymphoma in immunologically normal patients. AJNR Am. J. Neuroradiol. 13, 1207-1213.

Schneck, S.A., and Penn, I. (1970) Cerebral neoplasms associated with renal transplantation. Arch. Neurol. 22: 226-233.

Schneck, S.A., and Penn, I. (1971) De-novo brain tumours in renal-transplant recipients. Lancet 1, 983-986.

Schwaighofer, B.W., Hesselink, J.R., Press, G.A., Wolf, R.L., Healy, M.E., and Berthoty, D.P. (1989) Primary intracranial CNS lymphoma: MR manifestations. AJNR Am. J. Neuroradiol. 10, 725-729.

Schwechheimer, K., Braus, D.F., Schwarzkopf, G., Feller, A.C., Volk, B., and MullerHermelink, H.K. (1994) Polymorphous high-grade B cell lymphoma is the predominant type of spontaneous primary cerebral malignant lymphomas: Histological and immunomorphological evaluation of computed tomography-guided stereotactic brain biopsies. Am. J. Surg. Pathol. 18, 931-937.

Sherman, M.E., Erozan, Y.S., Mann, R.B., Kumar, A.A., McArthur, J.C., Royal, W., Uematsu S., and Nauta, H. (1991) Stereotactic brain biopsy in the 
diagnosis of malignant lymphoma. Am. J. Clin. Pathol. 95, 878-883.

Southern, E.M. (1975) Detection of specific sequences among DNA fragments separated by gel electrophoresis. Mol. Biol. 98, 503-517.

Tomlinson, F.H., Kurtin, P.J., Suman, V.J., Scheithauer, B.W., O'Fallon, J.R., Kelly, P.J., Jack, C.R., Jr., and O'Neill, B.P. (1995) Primary intracerebral malignant lymphoma: A clinicopathological study of 89 patients. Neurosurgery 82, 558-566

Tubman, D.E., Frick, M.P., and Hanto, D.W. (1983) Lymphoma after organ transplantation: Radiologic manifestations in the central nervous system, thorax, and abdomen. Radiology 149, 625-631.

van Diemen-Steenvoorde, R., Donckerwolcke, R.A., Kluin, P.M., Kapsenberg, J.G., Lepoutre, J.M., Fleer, A., Kuis, W., and Stoop, J.W. (1986) EpsteinBarr virus related central nervous system lymphoma in a child after renal transplantation. Int. J. Pediatr. Nephrol. 7, 55-58.

Walker, R.C., Marshall, W.F., Strickler, J.G., Wiesner, R.H., Velosa, J.A., Habermann, T.M., McGregor, C.G., and Paya, C.V. (1995) Pretransplantation assessment of the risk of lymphoproliferative disorder. Clin. Infect. Dis. 20, 1346-1353.

Weintraub, J., and Warnke, R.A. (1982) Lymphoma in cardiac allotransplant recipients: Clinical and histological features and immunological phenotype. Transplantation 33, 347-351.

Wood, A., Angus, B., Kestevan, P., Dark, J., Notarianni, G., Miller, S., Howard, M., Proctor, S., and Middleton, P. (1997) Alpha interferon gene deletions in post-transplant lymphoma. Br. J. Haematol. 98, 1002-1003.

Zimmerman, R.A., and Bilaniuk, L.T. (1980) Computed tomography of acute intratumoral hemorrhage. Radiology 135, 355-359. 